\title{
Neonicotinoids - systemic insecticides in plant protection
}

\section{Neonikotynoidy - insektycydy systemiczne w ochronie roślin}

\author{
Monika Michel*
}

\section{Summary}

Neonicotinoids are the active substances of systemic insecticides that have a neuroactive effect, used in plant protection products to combat harmful insects. The aim of the study was to present synthetically the most important aspects regarding the properties of neonicotinoid compounds, their applications and analytical methods for determination based on a review of selected world literature.

Key words: neonicotionids, plant protection, physico-chemical characteristic, mode of action, residue determination

\section{Streszczenie}

Neonikotynoidy to substancje czynne insektycydów systemicznych o działaniu neuroaktywnym, stosowane w środkach ochrony roślin do zwalczania szkodliwych owadów. Celem pracy było syntetyczne przedstawienie najistotniejszych aspektów dotyczących właściwości związków neonikotynoidowych, ich zastosowania i analitycznych metod oznaczania w oparciu o przegląd wybranej literatury światowej.

Słowa kluczowe: neonikotynoidy, ochrona roślin, charakterystyka fizykochemiczna, sposób działania, oznaczanie pozostałości

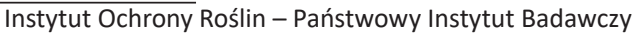

Władysława Węgorka 20, 60-318 Poznań

*corresponding author: m.michel@iorpib.poznan.pl

ORCID: 0000-0001-7841-0219 


\section{Neonikotynoidy - środki nowej generacji / Neonicotinoids - new generation agents}

Stale rosnące zapotrzebowanie na środki ochrony roślin oraz różnorodność upraw sprawia, że koncerny chemiczne opracowują i wprowadzają na rynek nowe, bardziej skuteczne, ale i często bardziej toksyczne pestycydy. Niewątpliwie do środków nowej generacji można zaliczyć preparaty owadobójcze (insektycydy) z grupy neonikotynoidów. Do związków tych zalicza się m.in.: acetamipryd, tiachlopryd, imidachlopryd, chlotianidyna, tiametoksam, dinotefuran i nitenpyram (Casida 2010; Casida i Durkin 2013; Cutler i wsp. 2013) (tab. 1). Odkrycie ich przyczyniło się znacząco do rozwoju agrochemii w przeciągu ostatnich kilkudziesięciu lat. Wprowadzone zostały do obrotu w połowie lat 90. $\mathrm{XX}$ wieku i od tego czasu stały się najszybciej zyskującą na znaczeniu grupą insektycydów stosowanych w ochronie upraw przed szkodnikami. Dopuszczono je do stosowania w ponad 120 krajach na świecie i w uprawie przeszło 1000 gatunków roślin.

Powszechność stosowania neonikotynoidów wynika z wysoce selektywnego działania. Ich toksyczność dla ssaków, ryb i ptaków jest niska. Wykazują znacznie lepszy efekt w zwalczaniu szkodliwych owadów odpornych na środki owadobójcze, w tym związki fosforoorganiczne, karbaminianowe i z grupy pyretroidów (Watanabe 2012). Jednakże pojawiają się informacje o możliwym negatywnym wpływie neonikotynoidów na ekosystem związany z pożytecznymi owadami, m.in. zapylającymi. Powoduje to konieczność prowadzenia dalszych badań w aspekcie bezpieczeństwa żywności, w tym upraw, oraz wpływu na środowisko dla zarządzania ryzykiem i jego oceny.

\section{Charakterystyka neonikotynoidów I Characteristics of neonicotinoids}

Neonikotynoidy to grupa neuroaktywnych insektycydów o strukturze chemicznej podobnej do struktury nikotyny, będącej już w latach 30. XX wieku powszechnie używaną jako insektycyd. Napary z nikotyny zalecane były do zwalczania wielu gatunków szkodników. Dla przykładu: zadymiano szklarnie poprzez spalanie nikotyny zwalczając mszyce i inne szkodniki upraw szklarniowych. Nikotyna to naturalny alkaloid zawarty w liściach tytoniu, niezwykle toksyczny dla ssaków (Tomizawa i Casida 2005; Watanabe 2012). Właściwości te zainicjowały badania $\mathrm{z}$ wykorzystaniem nikotyny jako związku modelowego w celu opracowania nowych pestycydów o wysoce selektywnej toksyczności. W latach 70. XX wieku firma Shell opracowała związki zbudowane $\mathrm{z}$ nasyconych sześcioczłonowych heterocyklicznych pierścieni. Wykazywały one bardzo silne właściwości owadobójcze. Dalsze badania prowadzone przez Shell doprowadziły do odkrycia jeszcze skuteczniejszego insek- tycydu - nitiazyny (Soloway i wsp. 1978, 1979) (rys. 1). Był to związek, który jako pierwszy wykazywał mechanizm działania zbliżony do obecnie stosowanych neonikotynoidów. Jednak szybka degradacja nitiazyny podczas prób polowych nie pozwoliła na skomercjalizowanie tego związku.

Dopiero wprowadzenie do związku nitiazyny grup chromoforowych zapobiegło jego degradacji pod wpływem promieni słonecznych. Ta modyfikacja doprowadziła do odkrycia obecnie stosowanych neonikotynoidów. Imidachlopryd jest pierwszym przedstawicielem neonikotynoidów, który został zarejestrowany do użytku i pozostaje najważniejszym produktem handlowym (rys. 2). Związek został opracowany w 1984 roku przez chemików z Nihon Bayer Agrochem, którzy badali wprowadzenie grupy 3-pirydylometylowej do struktury heterocyklu nitrometylenowego (Shiokawa i wsp. 1986). Wykazano, że wprowadzenie tego ugrupowania znacznie zwiększa aktywność owadobójczą i zmniejsza toksyczność u ssaków (Kagabu i wsp. 1992), zachowując jednocześnie wiele innych właściwości związku, które są ważne dla zastosowania komercyjnego.

Neonikotynoidy są niejednorodną grupą chemiczną. W swojej budowie zawierają łańcuch otwarty lub pięcioalbo sześcioczłonowy pierścień (rys. 3). Acetamipryd i chlotianidyna to związki mające łańcuch otwarty, natomiast tiametoksam, imidachlopryd i tiachlopryd - pięcio- lub sześcioczłonowy pierścień.

Neonikotynoidy mogą zawierać jedną z dwóch grup funkcyjnych. Chlotianidyna, imidachlopryd oraz tiametoksam posiadają w swojej budowie grupę nitroguanidynową (N-nitrowa), natomiast acetamipryd i tiachlopryd mają grupę cyjanoamidową. Związki posiadające grupę N-nitrową są znacznie bardziej polarne i reaktywne od tych, które mają grupę cyjanoamidową. Zwiększona polarność i reaktywność spowodowana jest dodatkowym atomem tlenu, który wchodzi w skład grupy N-nitrowej (Ford i Casida 2008; Jeschke i Nauen 2008). Rodzaj grupy funkcyjnej oraz jej przestrzenne rozmieszczenie z podstawnikami chemicznymi decyduje o aktywności biologicznej związku, jego toksyczności oraz odpowiada za niektóre właściwości fizykochemiczne, takie jak degradacja fotolityczna czy rozkład w glebie.

Z powodu zróżnicowanej budowy, neonikotynoidy wykazują zróżnicowaną toksyczność: acetamipryd i tiachlopryd są mało toksyczne, natomiast toksyczność tiametoksamu, chlotianidyny i imidachloprydu jest znacznie większa. Związki te można również podzielić na: pochodne chloro-pirydyny - imidachlopryd, acetamipryd, tiachlopryd oraz pochodne chloro-tiazolu - chlotianidyna, tiametoksam. Najważniejsze właściwości fizykochemiczne zestawiono w tabeli 2 .

Wszystkie neonikotynoidy są biodegradowalne i nie ulegają akumulacji w ogniwach łańcucha pokarmowego ssaków. Związki te działają systemicznie - pobierane są przez rośliny i transportowane do wszystkich tkanek. Są dobrze rozpuszczalne w wodzie. Długi okres rozpadu neonikoty- 
Tabela 1. Nazwy chemiczne IUPAC, wzory sumaryczne i struktura neonikotynoidów (https://pubchem.ncbi.nlm.nih.gov/compound/ Imidacloprid, https://sitem.herts.ac.uk/aeru/ppdb/en/Reports/631.htm\#trans)

Table 1. IUPAC names, molecular formulas, and structures of neonicotinoids (https://pubchem.ncbi.nlm.nih.gov/compound/Imidacloprid, https://sitem.herts.ac.uk/aeru/ppdb/en/Reports/631.htm\#trans)

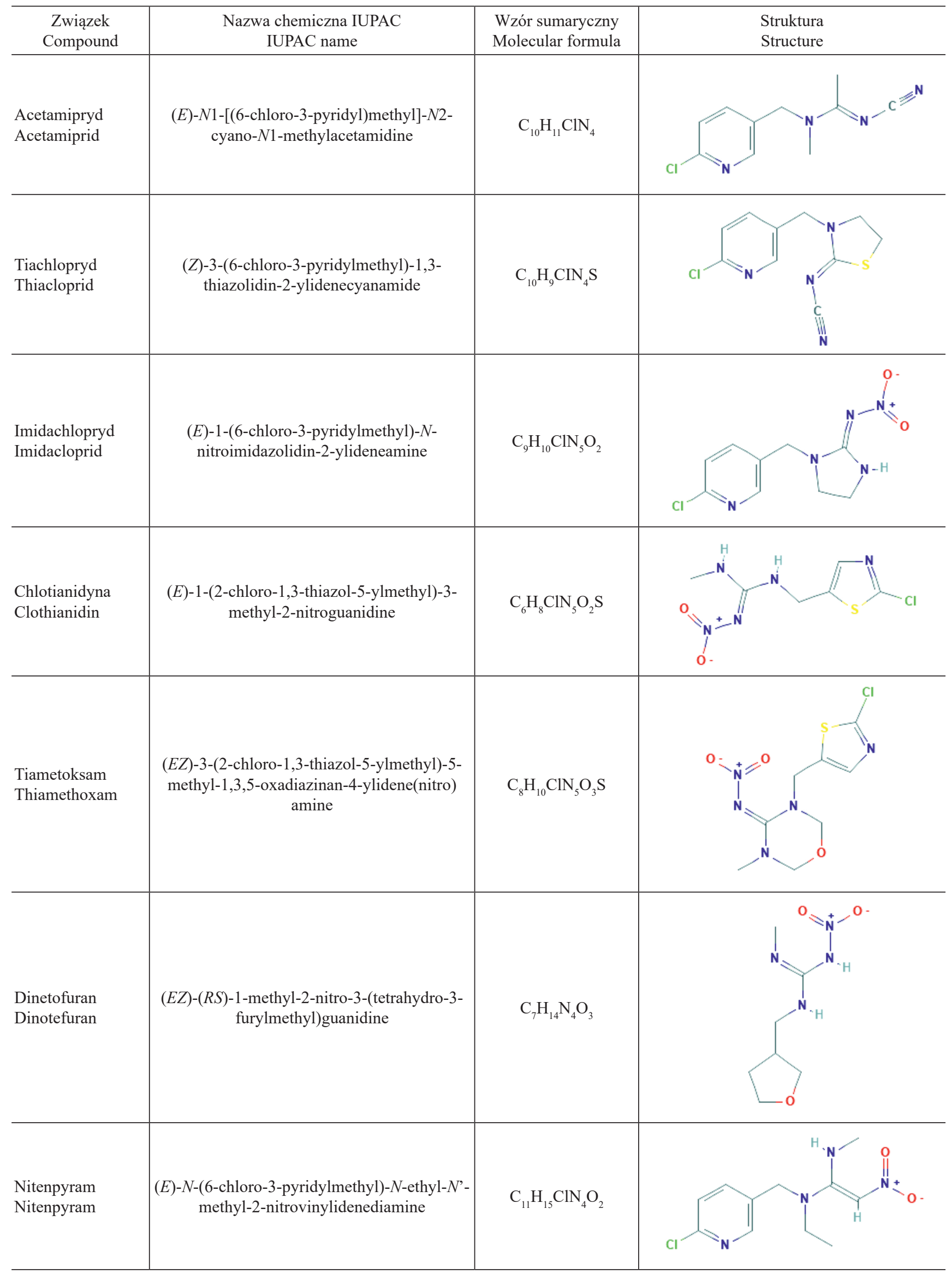


<smiles>CN1CCCC1c1cccnc1</smiles>

Nikotyna (a) Nicotine (a)<smiles>O=[N+]([O-])C=C1NCCCS1</smiles>

Nitriazyna (b) Nitrazine (b)

Rys. 1. Struktura nikotyny (a) i nitiazyny (b) (Watanabe 2012)

Fig. 1. Structure of nicotine (a) and nitiazine (b) (Watanabe 2012)<smiles>O=[N+]([O-])NC1=NCCN1Cc1ccc(Cl)nc1</smiles>

Rys. 2. Struktura imidachloprydu (Watanabe 2012)

Fig. 2. Structure of imidacloprid (Watanabe 2012)

noidów umożliwia długotrwałą ochronę upraw. Mogą być obecne i aktywne w glebie, wodzie, roślinie uprawnej, uprawach następczych oraz roślinach towarzyszących uprawom, nawet na długo po tym, jak zostaną zastosowane w konkretnej roślinie uprawnej. Preparaty zawierające neonikotynoidy cechuje wielopostaciowość: mogą być stosowane jako<smiles>CCNC(=NC)NC</smiles>

(a)<smiles>CCN(CC)C1=NCCN1CC</smiles>

$\mathrm{R}=\mathrm{NH}, \mathrm{S}$

(b)<smiles>CN=C1N(C)COCN1C</smiles>

(c)
Rys. 3. Elementy struktury neonikotynoidów: otwarty łańcuch (a), pięcioczłonowy pierścień (b), sześcioczłonowy pierścień (c)

Fig. 3. Elements of neonicotinoids structure: open chain (a), fivemembered ring (b), six-membered ring (c)

środki nalistne, zaprawy do nasion, wprowadzane w postaci granulatów do wody i gleby, można nimi traktować korzenie lub cebule młodych roślin, nastrzykiwać pnie drzew. Są $\mathrm{z}$ zasady stosowane prewencyjnie.

Wysoka selektywność działania na receptor acetylocholiny i wynikająca $\mathrm{z}$ tego szybka reakcja $\mathrm{z}$ ośrodkowym układem nerwowym owadów, zapewnia wysoką skuteczność neonikotynoidów. W większych dawkach u owadów powodują paraliż, zaburzenia lokomotoryczne, zaburzenia pamięci, a w ich następstwie śmierć osobników.

Głównym neuroprzekaźnikiem odpowiadającym za prawidłowe funkcjonowanie mózgu owadów jest nikotynowy receptor acetylocholiny, którego neonikotynoidy są antagonistami. Związki te wykazują bardziej selektywne dzia-

Tabela 2. Właściwości fizykochemiczne neonikotynoidów (https://pubchem.ncbi.nlm.nih.gov/compound/Imidacloprid, https://sitem. herts.ac.uk/aeru/ppdb/en/Reports/631.htm\#trans) (MacBean 2012)

Table 2. Physicochemical properties of neonicotinoids (https://pubchem.ncbi.nlm.nih.gov/compound/Imidacloprid, https://sitem.herts. ac.uk/aeru/ppdb/en/Reports/631.htm\#trans) (MacBean 2012)

\begin{tabular}{l|c|c|c|c|c}
\hline \multicolumn{1}{c|}{$\begin{array}{c}\text { Związek } \\
\text { Compound }\end{array}$} & $\begin{array}{c}\text { Masa molowa } \\
\text { Molar mass } \\
{[\mathrm{g} / \mathrm{mol}]}\end{array}$ & $\begin{array}{c}\text { Gęstość } \\
\text { Density } \\
{\left[\mathrm{g} / \mathrm{l} ; 20^{\circ} \mathrm{C}\right]}\end{array}$ & $\begin{array}{c}\text { Współczynnik podziału } \\
\text { oktanol/woda } \\
\text { Octanol/water partioion } \\
\text { coefficient } \\
\text { logP } \\
{\left[25^{\circ} \mathrm{C}\right]}\end{array}$ & $\begin{array}{c}\text { Stała dysocjacji } \\
\text { Dissociation constans } \\
\mathrm{pKa}\end{array}$ & $\begin{array}{c}\text { Rozpuszczalność } \\
\text { W wodzie } \\
\text { Solubility in water } \\
{\left[\mathrm{mg} / 1 ; 25^{\circ} \mathrm{C}\right]}\end{array}$ \\
\hline $\begin{array}{l}\text { Acetamipryd } \\
\text { Acetamiprid }\end{array}$ & 222,67 & 1,33 & 0,80 & 0,7 & 2950 \\
\hline $\begin{array}{l}\text { Tiachlopryd } \\
\text { Thiacloprid }\end{array}$ & 252,72 & 1,46 & 1,26 & $\mathrm{n} / \mathrm{a}$ & 185 \\
\hline $\begin{array}{l}\text { Imidachlopryd } \\
\text { Imidacloprid }\end{array}$ & 255,66 & 1,54 & 0,57 & 11,1 & 601 \\
\hline $\begin{array}{l}\text { Chlotianidyna } \\
\text { Clothianidin }\end{array}$ & 249,70 & 1,61 & 0,73 & $\mathrm{n} / \mathrm{a}$ & 340 \\
\hline $\begin{array}{l}\text { Tiametoksam } \\
\text { Thiamethoxam }\end{array}$ & 291,71 & 1,57 & $-0,13$ & 12,6 & 4100 \\
\hline $\begin{array}{l}\text { Dinetofuran } \\
\text { Dinotefuran }\end{array}$ & 202,21 & 1,42 & $-0,55$ & 3,1 & 3983 \\
\hline $\begin{array}{l}\text { Nitenpyram } \\
\text { Nitenpyram }\end{array}$ & 270,72 & 1,40 & $-0,66$ & 590 \\
\hline
\end{tabular}


łanie wśród owadów niż ssaków. Receptor acetylocholiny zbudowany jest z kanałów jonowych, które pośredniczą w szybkiej, cholinergicznej transmisji pomiędzy synapsami. Dochodzi w ten sposób do oddziaływania na nerwy mięśniowe i silnie rozbudowany ośrodkowy układ nerwowy owadów (Shiokawa i wsp. 1994; Tomizawa 1994; Kagabu 1996; Tomizawa i Casida 2005, 2011).

Acetylocholina docierając do powierzchni receptora wywołuje depolaryzację błony postsynaptycznej, co powoduje otwarcie kanałów jonowych przepuszczających jony $\mathrm{Na}^{+}$i $\mathrm{K}^{+}$. Transmisja jonów w kanałach prowadzi do pobudzenia włókien mięśniowych (rys. 4). Neonikotynoidy wypierają acetylocholinę i wiążą się z receptorem, co skutkuje osłabieniem sygnału nerwowego. Słabsze przewodnictwo zmniejsza lub nie powoduje depolaryzacji błony postsynaptycznej, w wyniku czego nie dochodzi do pobudzenia włókien mięśniowych. Doprowadza to do zaburzeń lokomotorycznych i pamięci. Może być przyczyną degradacji struktur komórkowych mózgu, co przy długotrwałym okresie prowadzi do śmierci owada.

Neonikotynoidy są dobrze rozpuszczalne w wodzie, co powoduje, że po podaniu doustnym u ssaków wydalane są wraz z moczem (w postaci niezmienionej). W płodach rolnych ulegają złożonym reakcjom fotochemicznym i procesom metabolicznym. Doprowadza to, w zależności od mechanizmu reakcji, do powstania takich samych lub odmiennych metabolitów i powoduje, że oznaczanie pozostałości pestycydów nie ogranicza się tylko do związków macierzystych, ale również do ich metabolitów. Neonikotynoidy podczas szlaków metabolicznych ulegają hydroksylacji, podstawieniom metylenowym oraz dehydratacji. Dochodzić może do rozerwania pierścienia oraz utleniania aldehydów do kwasów karboksylowych. Metabolitami imidachloprydu są pochodne z ugrupowaniami chloro-pirydynowymi. Tiachlopryd rozpada się na związki amidowe i hydroksylowe. Za metabolit tiametoksamu uważa się chlotianidynę. Acetamipryd i chlotianidyna występuje tylko w postaci macierzystej.

\section{Neonikotynoidy a pszczoły / Neonicotinoids and bees}

Jednym z najpoważniejszych zagrożeń dla rodzin pszczelich jest zespół masowego ginięcia pszczoły miodnej (colony collapse disorder - CCD). Jego dokładne przyczyny nie są do końca rozpoznane. Podaje się kilka czynników: pasożytujące na pszczołach roztocza, wirusy, bakterie, obniżenie odporności pszczół, utrata siedlisk, fale elektromagnetyczne zakłócające system nawigacyjny, zatrucia pestycydami, niedochowanie prawidłowych praktyk rolniczych i pszczelarskich, zmiany klimatu.

Entomolog prof. Michael Burgett z Oregon State University, autor raportu USDA (Departament Rolnictwa Stanów Zjednoczonych) z marca 2018 roku na temat kondycji pszczół w Stanach Zjednoczonych mówi, że ,jeżeli stworzyłoby się listę 10 głównych czynników powodujących ginięcie kolonii pszczelich, to pestycydy umieściłoby się na miejscu 11" (Ferrier i wsp. 2018).

Kwestia bezpieczeństwa zapylaczy w kontekście stosowania chemicznych środków ochrony roślin, która jest szeroko omawiana w Polsce i na świecie, znajduje odzwierciedlenie w zapisach Krajowego planu działania
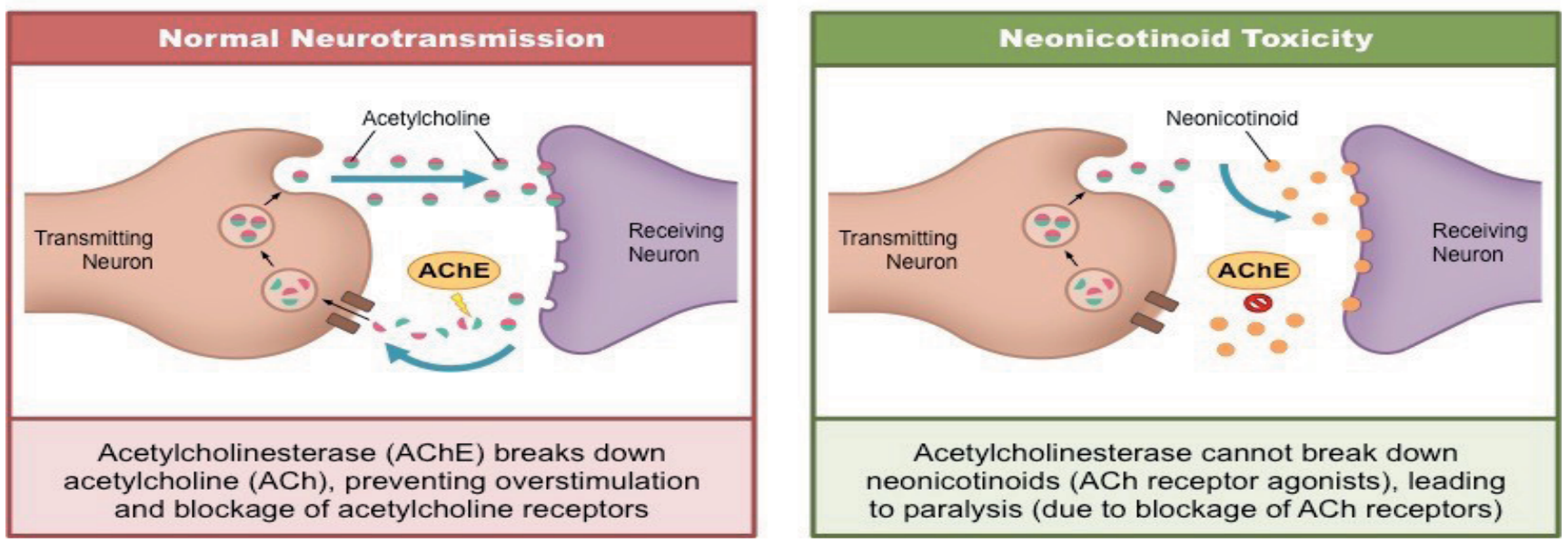

Rys. 4. Normalna neurotransmisja - acetylocholinesteraza (AChE) rozkłada acetylocholinę (ACh), zapobiegając nadmiernej stymulacji i blokowaniu receptora acetylocholiny. Toksyczność neonikotynoidowa - acetylocholinesteraza (AChE) nie może rozkładać neonikotynoidów (agonistów receptora $\mathrm{ACh}$ ), co prowadzi do paraliżu (z powodu zablokowania receptorów ACh) (www.bioninja. com.au)

Fig. 4. Normal neurotransmission - acetylcholinesterase (AChE) breaks down acetylcholine (ACh), preventing overstimulation and blocking of acetylcholine receptor. Neonicotinoid toxicity - acetylcholinesterase (AChE) cannot break down neonicotinoids (ACh receptor agonists), leading to paralysis (due to blockage of ACh receptors) (www.bioninja.com.au) 
na rzecz ograniczenia ryzyka związanego ze stosowaniem środków ochrony roślin na lata 2018-2022 (MRiRW 2018). Wpływ substancji czynnych z grupy neonikotynoidów na pszczoły nadal nie został jednoznacznie rozstrzygnięty. Zlecona przez Komisję Europejską do EFSA(Europejskiego Urzędu ds. Bezpieczeństwa Żywności) ocena danych naukowych nt. bezpieczeństwa dla pszczół w następstwie stosowania neonikotynoidów ma złożony charakter i składa się z szeregu odrębnych naukowych ocen, dotyczących potencjalnie szkodliwego działania substancji czynnych dla pszczół i innych zapylaczy (EFSA 2013).

Część przeprowadzonych eksperymentów wskazywała na negatywny wpływ neonikotynoidów, ale były one wykonywane w warunkach laboratoryjnych, gdzie pszczoły poddawano działaniu bardzo wysokich dawek pestycydów, nieodzwierciedlających rzeczywistych warunków. Dlatego najbardziej miarodajne są badania przeprowadzone na polach w naturalnych warunkach. Niestety, dla ogromnej części gatunków dzikich pszczół i innych zapylaczy (motyli, muchówek, chrząszczy) wciąż nie przeprowadzono odpowiednich, wiarygodnych badań. Nie ocalimy pszczół bez rzetelnej i merytorycznej analizy wpływu pestycydów na ich życie. Jednak to właśnie użycie pestycydów podlega naszej największej kontroli. Poza tym, jednym z istotnych obszarów, gdzie potrzebne są dalsze badania, jest kwestia łącznego stosowania kilku środków ochrony roślin.

\section{Metody oznaczania pozostałości neonikotynoidów / Methods for the determination of neonicotinoid residues}

Przegląd aktualnych metod analitycznych z wykorzystaniem technik chromatograficznych i niechromatograficz- nych dla pozostałości insektycydów neonikotynoidowych zebrany został w następujących publikacjach: MacDonald i Meyer (1998), Fernández-Alba i wsp. (2000), Pous i wsp. (2001), Vilchez i wsp. (2001), Blasco i wsp. (2002), Singh i wsp. (2004), Byrne i wsp. (2005), Lehotay i wsp. (2005), Liu i wsp. (2005), Kim i wsp. (2006), Totti i wsp. (2006), Xu i wsp. (2006, 2010), Ferrer i Thurman (2007), Payá i wsp. (2007), Watanabe i wsp. (2007), Eisenback i wsp. (2008), Frenich i wsp. (2008), Kmellár i wsp. (2008, 2011), Ma i wsp. (2009), Radišić i wsp. (2009), García-Chao i wsp. (2010), Kamel (2010), Lara i wsp. (2010), Llorent-Martínez i wsp. (2011), Romero-González i wsp. (2011), Watanabe (2012).

Autorzy tych publikacji przytaczają z obszernej literatury metody analityczne, które stanowią podstawę niezbędną do badań nad analizą ilościową i jakościową zebranego materiału oraz do zarządzania ryzykiem i oceny ryzyka dla insektycydów neonikotynoidowych w celu usystematyzowania wiedzy, a także uporządkowania trendu, obecnej sytuacji oraz przyszłych kierunków badań.

Metody analityczne oparte są głównie na technikach chromatograficznych, takich jak chromatografia gazowa (GC - gas chromatography) oraz chromatografia cieczowa (LC - liqiud chromatography) sprzężone ze spektometrią mas (MS - mass spectrometry), procedury wstępnej obróbki próbek przed oznaczeniem chromatograficznym, ekstrakcja z materiału oraz oczyszczanie. Zebrane są również metody analityczne oparte na technikach niechromatograficznych, takich jak analiza przepływowo-wstrzykowa (FIA - flow injection analysis) lub spektrometria mas do bezpośredniego oznaczenia insektycydów neonikotynoidowych oraz analiza immunoenzymatyczna ELISA (enzyme-linked immunosorbent assay) jako szybka i prosta metoda wstępnego badania przesiewowego.

\section{Literatura / References}

Blasco C., Fernández M., Picó Y., Font G., Mańes J. 2002. Simultaneous determination of imidacloprid, carbendazim, methiocarb and hexythiazox in peaches and nectarines by liquid chromatography - mass spectrometry. Analytica Chimica Acta 461 (1): $109-116$. DOI: $10.1016 / \mathrm{S} 0003-2670(02) 00255-6$

Byrne F.J., Toscano N.C., Urena A.A., Morse J.G. 2005. Quantification of imidacloprid toxicity to avocado thrips, Scirtothrips perseae Nakahara (Thysanoptera: Thripidae), using a combined bioassay and ELISA approach. Pest Management Science 61 (8): 754-758. DOI: $10.1002 /$ ps. 1052

Casida J.E. 2010. Neonicotinoid metabolism: compounds, substituents, pathways, enzymes, organisms, and relevance. Journal of Agricultural and Food Chemistry 59 (7): 2923-2931. DOI: 10.1021/jf102438c

Casida J.E., Durkin K. 2013. Neuroactive insecticides: targets, selectivity, resistance, and secondary effects. Annual Review of Entomology 58: 99-117. DOI: 10.1146/annurev-ento-120811-153645

Cutler P., Slater R., Edmunds J.F., Maienfisch P., Hall R.G., Earley G.P., Pitterna T., Pal S., Paul V.-L., Goodchild J., Blacker M., Hagmann L., Crossthwaite A.J. 2013. Investigating the mode of action of sulfoxaflor: a fourth-generation neonicotinoid. Pest Management Science 69 (5): 607-619. DOI: 10.1002/ps.3413

EFSA 2013. EFSA identifies risks to bees from neonicotinoids. https://www.efsa.europa.eu/en/press/news/130116 [dostęp: 16.01.2013].

Eisenback B.M., Mullins D.E., Salom S.M., Kok L.T. 2008. Evaluation of ELISA for imidacloprid detection in eastern hemlock (Tsuga canadensis) wood and needle tissues. Pest Management Science 65 (2): 122-128. DOI: 10.1002/ps.1655

Fernández-Alba A.R., Tejedor A., Agüera A., Contreras M., Garrido J. 2000. Determination of imidacloprid and benzimidazole residues in fruits and vegetables by liquid chromatography - mass spectrometry after ethyl acetate multiresidue extraction. Journal of AOAC International 83 (3): 748-755.

Ferrer I., Thurman E.M. 2007. Multi-residue method for the analysis of 101 pesticides and their degradates in food and water samples by liquid chromatography/time-of-flight mass spectrometry. Journal of Chromatography A 1175 (1): 24-37. DOI: 10.1016/j. chroma.2007.09.092 
Ferrier P.M., Rucker R.R., Thurman W.N., Burgett M. 2018. Economic Effects and Responses to Changes in Honey Bee Health. Economic Research Report 246. United States Department of Agriculture, Economic Research Service, March 2018, 54 ss.

Ford K.A., Casida J.E. 2008. Comparative metabolism and pharmacokinetics of seven neonicotinoid insecticides in spinach. Journal of Agricultural and Food Chemistry 56 (21): 10168-10175. DOI: 10.1021/jf8020909

Frenich A.G., Vidal J.L.M., Pastor-Montoro E., Romero-González R. 2008. High-throughput determination of pesticide residues in food commodities by use of ultra-performance liquid chromatography - tandem mass spectrometry. Analytical and Bioanalytical Chemistry 390 (3): 947-959. DOI: 10.1007/s00216-007-1746-5

García-Chao M., Agruńa M.J., Calvete G.F., Sakkas V., Llompart M., Dagnac T. 2010. Validation of an off line solid phase extraction liquid chromatography - tandem mass spectrometry method for the determination of systemic insecticide residues in honey and pollen samples collected in apiaries from NW Spain. Analytica Chimica Acta 672 (1-2): 107-113. DOI: 10.1016/j.aca.2010.03.011

Jeschke P., Nauen R. 2008. Neonicotinoids - from zero to hero in insecticide chemistry. Pest Management Science 64 (11): $1084-1098$. DOI: $10.1002 /$ ps.1631

Kagabu S. 1996. Studies on the synthesis and insecticidal activity of neonicotinoid compounds. Journal of Pesticide Science 21 (2): 231-239. DOI: 10.1584/jpestics.21.231

Kagabu S., Moriya K., Shibuya K., Hattori Y., Tsuboi S., Shiokawa K. 1992. 1-(6-halonicotinyl-2-nitromethylene-imidazolidines as potential new insecticides. Bioscience, Biotechnology, and Biochemistry 56 (2): 362-363. DOI: 10.1271/bbb.56.362

Kamel A. 2010. Refined methodology for the determination of neonicotinoid pesticides and their metabolites in honey bees and bee products by liquid chromatography - tandem mass spectrometry (LC-MS/MS). Journal of Agricultural and Food Chemistry 58 (10): 5926-5931. DOI: 10.1021/jf904120n

Kim H.-J., Shelver W.L., Hwang E.-C., Xu T., Li Q.X. 2006. Automated flow fluorescent immunoassay for part per trillion detection of the neonicotinoid insecticide thiamethoxam. Analytica Chimica Acta 571 (1): 66-73. DOI: 10.1016/j.aca.2006.04.084

Kmellár B., Fodor P., Pareja L., Ferrer C., Martínez-Uroz M.A., Valverde A., Fernandez-Alba A.R. 2008. Validation and uncertainty study of a comprehensive list of 160 pesticide residues in multi-class vegetables by liquid chromatography - tandem mass spectrometry. Journal of Chromatography A 1215 (1-2): 37-50. DOI: 10.1016/j.chroma.2008.10.121

Kmellár B., Pareja L., Ferrer C., Fodor P., Fernandez-Alba A.R. 2011. Study of the effects of operational parameters on multiresidue pesticide analysis by LC-MS/MS. Talanta 84 (2): 262-273. DOI: 10.1016/j.talanta.2010.12.006

Lara F.J., García-Campańa A.M., Aaron J.-J. 2010. Analytical applications of photoinduced chemiluminescence in flow systems A review. Analytica Chimica Acta 679 (1-2): 17-30. DOI: 10.1016/j.aca.2010.09.001

Lehotay S.J., de Kok A., Hiemstra M., van Bodegraven P. 2005. Validation of a fast and easy method for the determination of residues from 229 pesticides in fruits and vegetables using gas and liquid chromatography and mass spectrometric detection. Journal of AOAC International 88 (2): 595-614.

Liu H., Song J., Zhang S., Qu L., Zhao Y., Wu Y., Liu H. 2005. Analysis of residues of imidacloprid in tobacco by high-performance liquid chromatography with liquid-liquid partition cleanup. Pest Management Science 61 (5): 511-514. DOI: 10.1002/ps.987

Llorent-Martínez E.J., Ortega-Barrales P., Fernández-de Córdova M.L., Ruiz-Medina A. 2011. Trends in flow-based analytical methods applied to pesticide detection: A review. Analytica Chimica Acta 684 (1-2): 30-39. DOI: 10.1016/j.aca.2010.10.036

Ma H., Xu Y., Li Q.X., Xu T., Wang X., Li J. 2009. Application of enzyme-linked immunosorbent assay for quantification of the insecticides imidacloprid and thiamethoxam in honey samples. Food Additives and Contaminants: Part A 26 (5): 713-718. DOI: $10.1080 / 02652030802672638$

MacBean C. (red.). 2012. A World Compendium. The Pesticide Manual. Sixteenth Edition. British Crop Production Council, Hampshire, UK, 561 ss. ISBN 978-1901396-86-7.

MacDonald L.M., Meyer T.R. 1998. Determination of imidacloprid and triadimefon in white pine by gas chromatography/mass spectrometry. Journal of Agricultural and Food Chemistry 46 (8): 3133-3138. DOI: 10.1021/jf9800357

MRiRW 2018. Krajowy plan działania na rzecz ograniczenia ryzyka związanego ze stosowaniem środków ochrony roślin na lata 2018-2022. https://www.gov.pl/web/rolnictwo/stosowanie-srodkow-ochrony-roslin-krajowy-plan-dzialania [dostęp: 17.07.2018].

Payá P., Anastassiades M., Mack D., Sigalova I., Tasdelen B., Oliva J., Barba A. 2007. Analysis of pesticide residues using the Quick Easy Cheap Effective Rugged and Safe (QuEChERS) pesticide multiresidue method in combination with gas and liquid chromatography and tandem mass spectrometric detection. Analytical and Bioanalytical Chemistry 389 (6): 1697-1714. DOI: 10.1007/s00216-007$1610-7$

Pous X., Ruís M.J., Picó Y., Font G. 2001. Determination of imidacloprid, metalaxyl, myclobutanil, propham, and thiabendazole in fruits and vegetables by liquid chromatography - atmospheric pressure chemical ionization-mass spectrometry. Fresenius Journal of Analytical Chemistry 371 (2): 182-189. DOI: 10.1007/s002160100946

Radišić M., Grujić S., Vasiljević T., Laušević M. 2009. Determination of selected pesticides in fruit juices by matrix solid-phase dispersion and liquid chromatography - tandem mass spectrometry. Food Chemistry 113 (2): 712-719. DOI: 10.1016/j.foodchem.2008.07.103

Romero-González R., Frenich A.G., Vidal J.L.M., Prestes O.D., Grio S.L. 2011. Simultaneous determination of pesticides, biopesticides and mycotoxins in organic products applying a quick, easy, cheap, effective, rugged and safe extraction procedure and ultra-high performance liquid chromatography - tandem mass spectrometry. Journal of Chromatography A 1218 (11): 1477-1485. DOI: 10.1016/j.chroma.2011.01.034

Shiokawa K., Tsuboi S., Iwaya K., Moriya K. 1994. Development of a chloronicotinyl insecticide, imidacloprid. Journal of Pesticide Science 19 (4): S209-S217. DOI: 10.1584/jpestics.19.4_S209

Shiokawa K., Tsuboi S., Kagabu S., Moriya K. 1986. (Nikon Bayer Agrochem K. K.): Jpn. Kokai Tokkyo Koho JP 61-267575.

Singh S.B., Foster G.D., Khan S.U. 2004. Microwave-assisted extraction for the simultaneous determination of thiamethoxam, imidacloprid, and carbendazim residues in fresh and cooked vegetable samples. Journal of Agricultural and Food Chemistry 52 (1): 105-109. DOI: $10.1021 / \mathrm{jf030358 \textrm {p }}$

Soloway S.B., Henry A.C., Kollmeyer W.D., Padgett W.M., Powell J.E., Roman S.A., Tieman C.H., Corey R.A., Horne C.A. 1978. Nitromethylene heterocycles as insecticides. s. 153-158. W: Pesticide and Venom Neurotoxicity (D.L. Shankland, R.M. Hollingworth, T. Smith Jr., red.). Springer US, Plenum Press, New York, 284 ss. ISBN 978-1-4615-8834-4. DOI: 10.1007/978-1-4615-8834-4

Soloway S.B., Henry A.C., Kollmeyer W.D., Padgett W.M., Powell J.E., Roman S.A., Tieman C.H., Corey R.A., Horne C.A. 1979. Nitromethylene insecticides. s. 206-217. W: Advances in Pesticide Science (H. Geissbüehler, G.T. Brooks, P.C. Kearney, red.). Pergamon Press, Oxford, 522 ss. ISBN 978-0080239309. 
Tomizawa M. 1994. Structure-activity relationships of nicotinoids and the related compounds. Journal of Pesticide Science 19 (4): S229-S240. DOI: 10.1584/jpestics.19.4 S229

Tomizawa M., Casida J.E. 2011. Neonicotinoid insecticides: highlights of a symposium on strategic molecular designs. Journal of Agricultural and Food Chemistry 59 (7): 2883-2886. DOI: 10.1021/jf103856c

Tomizawa M., Casida J.E. 2005. Neonicotinoid insecticide toxicology: Mechanisms of selective action. Annual Review of Pharmacology and Toxicology 45: 247-268. DOI: 10.1146/annurev.pharmtox.45.120403.095930

Totti S., Fernández M., Ghini S., Picó Y., Fini F., Mańes J., Girotti S. 2006. Application of matrix solid phase dispersion to the determination of imidacloprid, carbaryl, aldicarb, and their main metabolites in honeybees by liquid chromatography - mass spectrometry detection. Talanta 69 (3): 724-729. DOI: 10.1016/j.talanta.2005.11.012

Vilchez J.L., Valencia M.C., Navalón A., Molinero-Morales B., Capitán-Vallvey L.F. 2001. Flow injection analysis of the insecticide imidacloprid in water samples with photochemically induced fluorescence detection. Analytica Chimica Acta 439 (2): 299-305. DOI: 10.1016/S0003-2670(01)01039-X

Watanabe E. 2012. Review on Current Analytical Methods with Chromatographic and Nonchromatographic Techniques for New Generation Insecticide Neonicotinoids. s. 482-510. W: Insecticides - Advances in Integrated Pest Management (F. Perveen, red.). InTech, Rijeka, Croatia, 708 ss. ISBN 978-953-307-780-2.

Watanabe E., Baba K., Eun H. 2007. Simultaneous determination of neonicotinoid insecticides in agricultural samples by solid-phase extraction cleanup and liquid chromatography equipped with diode-array detection. Journal of Agricultural and Food Chemistry 55 (10): 3798-3804. DOI: $10.1021 / \mathrm{jf} 063140 \mathrm{~m}$

Xu T., Jacobsen C.M., Cho I.K., Hara A.H., Li Q.X. 2006. Application of an enzyme-linked immunosorbent assay for the analysis of imidacloprid in wiliwili tree, Erythrina sandwicensis O. Deg, for control of the wasp Quadrastichus erythrinae. Journal of Agricultural and Food Chemistry 54 (22): 8444-8449. DOI: 10.1021/jf062004e

Xu T., Wei K.-Y., Wang J., Ma H.-X., Li J., Xu Y.-J., Li Q.X. 2010. Quantitative analysis of the neonicotinoid insecticides imidacloprid and thiamethoxam in fruit juices by enzyme-linked immunosorbent assays. Journal of AOAC International 93 (1): 12-18. 